\title{
TROPHIC STATUS OF TWO GLACIAL LAKES, WEST AND EAST OKOBOJI, IN NORTHWEST IOWA. U.S.A.
}

\author{
ESTATUS TRÓFICO DE DOS LAGOS GLACIARES, OKOBOJI DEL OESTE \\ Y DEL ESTE, EN EL NOROESTE DE IOWA, USA
}

\author{
Humberto Campos Ortegal
}

\begin{abstract}
The lentic water system formed by the West and East Okoboji lakes and the Big Spirit lake was sampled in four stations spread through the Okoboji lacustrine system on October $9^{\text {th }}$, 1994. In these samples were determined chemical and biological parameters as depth, Secchi's depth, temperature, $\mathrm{pH}$, dissolved oxygen, electrical conductivity. The content of chlorophyll A between both lakes was also studied, including a comparison in zooplankton. In contrast with the shallow stations, in the deepest stations it was observed stratification due to the presence of thermoclyne and oxiclyne. For the comparison of chlorophyll between both Okoboji lakes, a one-way ANOVA test was applied. Results showed that there were statistically significant differences at 2-meter depth among the stations in both lakes but not in surface waters. Later, a Duncan Multiple Range test was performed to examine the nature of these differences. It showed that only Station SP in East Okoboji differed from the other three with respect to chlorophyll A. The zooplankton comparison showed no differences either in the presence of cladocerans calanoyds and ciclopoyds, or in the total amount of zooplankton. The behavior among the stations only showed statistically significant differences in ciclopoyds.
\end{abstract}

Key words: Trophic status, glacial lakes, zooplankton.

\section{RESUMEN}

El sistema de aguas lénticas formado por los lagos Okoboji del oeste, del este y el gran lago Spirit fue muestreado en cuatro estaciones distribuidas en el sistema lacustre Okoboji el 9 de octubre del año 1994. En las muestras se determinaron parámetros físicos, químicos y biológicos como profundidad, profundidad del disco Secchi, temperatura, $\mathrm{pH}$, oxígeno disuelto, conductividad eléctrica. También se comparó el contenido de clorofila A y zooplancton entre los lagos Okoboji. Se observó que las estaciones con mayor profundidad mostraban estratificación porque presentaban termoclina y oxiclina, pero no las someras. Para la comparación de clorofila entre ambos lagos Okoboji se aplicó análisis de varianza (ANDEVA) no observándose diferencias estadísticamente significativas en aguas superficiales, pero sí a dos metros de profundidad en y entre los lagos. Posteriormente se aplicó la prueba multirrango de Duncan para determinar el origen de las diferencias, mostrando que una de las estaciones del lago Okoboji del este difería de las otras tres en cuanto a la clorofila A. La comparación biológica muestra que ambos lagos no difieren en la presencia de cladóceros, calanoideos ni ciclopoideos, tampoco en la cantidad total de zooplancton. El comportamiento entre las cuatro estaciones, sólo mostró diferencias estadísticamente significativas en ciclopoideos.

Palabras clave: Estatus trófico, lagos glaciares, zooplancton.

\section{INTRODUCTION}

In lentic systems, like lakes and reservoirs, the water movement, heat budget, biota, physical and chemical parameters are important variables that determine the circulation or stagnation of waters. Additionally, these variables also impact the system's trophic status, due to cultural eutrophication or aging of the body of water. Nutrient loading rates can be correlated statistically with some internal lake properties. Among important variables which determine the trophic status of lakes within comparable geographic areas, include: water transparency, morphometric indices, extent of macrophyte growth, concentration and composition of algae, supply of fish food organism, dissolved oxygen concentrations, $\mathrm{pH}$, concentration of divalent metal ions, concentration of detrital material and plant nutrients, the ratio of watershed area to water volume and levels of nutrient inputs from the watershed.

1 Cedar Falls IOWA - USA, 1994.

Fecha de Recepción: 18 Enero 2006

Fecha de Aceptación: 21 Abril 2006 
The current study reports an analysis of West and East Okoboji lakes in northwest Iowa. These lakes are described in terms of several physical characteristics and various measures of physical and chemical data. The lakes are compared in relation to their trophic status assuming that chlorophyll is related to the phytoplankton that, in turn, represents the productivity level or trophic status of a lake.

\section{STUDY SITE DESCRIPTION}

In Northwest of Iowa the natural prairie lakes and wetlands were formed by the advance and retreat of the last continental ice sheet (Wisconsin glaciation). The lakes are in an area of morainal topography known as the Desmoines Lobe. The lakes under study are located in Dickinson County, in the northwest of Iowa. West Lake Okoboji, that will be represented in this report as WOK is in $43^{\circ}$ $23^{\prime} \mathrm{N}$ and $95^{\circ} 9^{\prime} \mathrm{W}$, is the biggest of these two lakes. It has greater volume and mean depth than East Okoboji. East Lake Okoboji, will be represented in this report as EOK and is in $43^{\circ} 24^{\prime} \mathrm{N}$ and $95^{\circ}$ $5^{\prime} \mathrm{W}$. Both lakes are in a watershed area primarily rural, with land coverage dominated by row crops and pastures, however the shorelines of these lakes (as it was sight) are largely occupied by vacation homes, resorts, and parks that might contribute urban effluent into the lakes (Fig. 1 and Table 1).

\section{STUDY METHODOLOGY}

\subsection{FIELD-WORK}

Data were collected at two stations in each lake on 09-10-94. The stations in WOK were Miller's Bay (MB) and the Deep Point (DP). In EOK, the stations were the Narrow (NR) and Stony Point (SP), Figure $\mathrm{N}^{\mathrm{o}} 1$.

For each variable and at each station measurements of dissolved oxygen, $\mathrm{pH}$, conductivity, depth, temperature, hardness, alkalinity, phosphate, nitrate, ammonia, and ammonium were taken with a portable electronic device (Sonde) at different levels of depth. All the equipments and devices belong to The University of Northern Iowa from Cedar Falls.

Water transparency was measured with a Secchi disk three times in every station. In the measurement of the transparency of a waterbody, it is necessary to be considered natural light, the time of day, and the shaded side of the boat. These samples were obtained under hazy, sunny, and windy conditions.

Plankton samples were obtained twice with a plankton net, at each station over a distance of ten meters. Plankton sample were drawn twice in three tows set. One set of plankton samples was stored in bottles that previously contained carbonated water. The other set were was stored on ice.

Bentho's sample were taken in every station, except for DP in WOK. These benthic samples were taken with a jaws dredge Eckman's type, rinsed through a 500 um sieve and stored in plastic bag.

\subsection{LABORATORY - WORK}

Water samples were measured for water hardness, alkalinity, orthophosphate, and nitrate - nitrogen $\left(\mathrm{N}-\mathrm{NO}_{3}{ }^{-}\right)$using standard methods from chemical test kits in the Iowa Lakeside Laboratory. Water from surface and bottom were filtered for dry weight and ash-free and chlorophyll and measured with standard methods.

\section{Table 1}

Resorts Around Lakes

\begin{tabular}{|l|l|}
\hline \multicolumn{2}{|c|}{ Resorts } \\
\hline 1. Beaches Resort & 18. Oaks Motel \\
\hline 2. Blue Lagoon Resort & 19. Country \\
\hline 3. Blue Lake Resort & 20. Palace Motel \\
\hline 4. Cass Bay Cottages & 21. Pick's Lakeshore Resort \\
\hline 5. Country Club Motel & 22. Pioneer Beach \\
\hline $\begin{array}{c}\text { 6. Crescent Beach } \\
\text { Lodge }\end{array}$ & $\begin{array}{c}\text { 23. Ramada Limited Spirit- } \\
\text { Lake/Okoboji }\end{array}$ \\
\hline 7. Crow's Nest Resort & 24. Sand Bar Beach Resort \\
\hline $\begin{array}{c}\text { 8. Cutty's Okoboji } \\
\text { Resort Club }\end{array}$ & 25. Shamrock Inn \\
\hline 9. Fillenwarth Beach & 26. Super 8 Motel \\
\hline 10. Four Seasons Resort & 27. The Inn Resort \\
\hline $\begin{array}{c}\text { 11. Francis Hospitality } \\
\text { Manor }\end{array}$ & 28. Triggs Lakeshore Motel \\
\hline 12. Gardner's Cottages & 29. Vergie's Southside Resort \\
\hline $\begin{array}{c}\text { 13. Hannah Marie } \\
\text { Country Inn \& Bistro }\end{array}$ & 30. Village East Resort \\
\hline 14. Hedge Row Resort & 31. Village West Resort \\
\hline 15. Lakeshore Motel & 32. West Oaks Resort \\
\hline $\begin{array}{l}\text { 16. Moorland Country } \\
\text { 17. Northland Inn }\end{array}$ & 33. White Oaks Campground \\
\hline
\end{tabular}




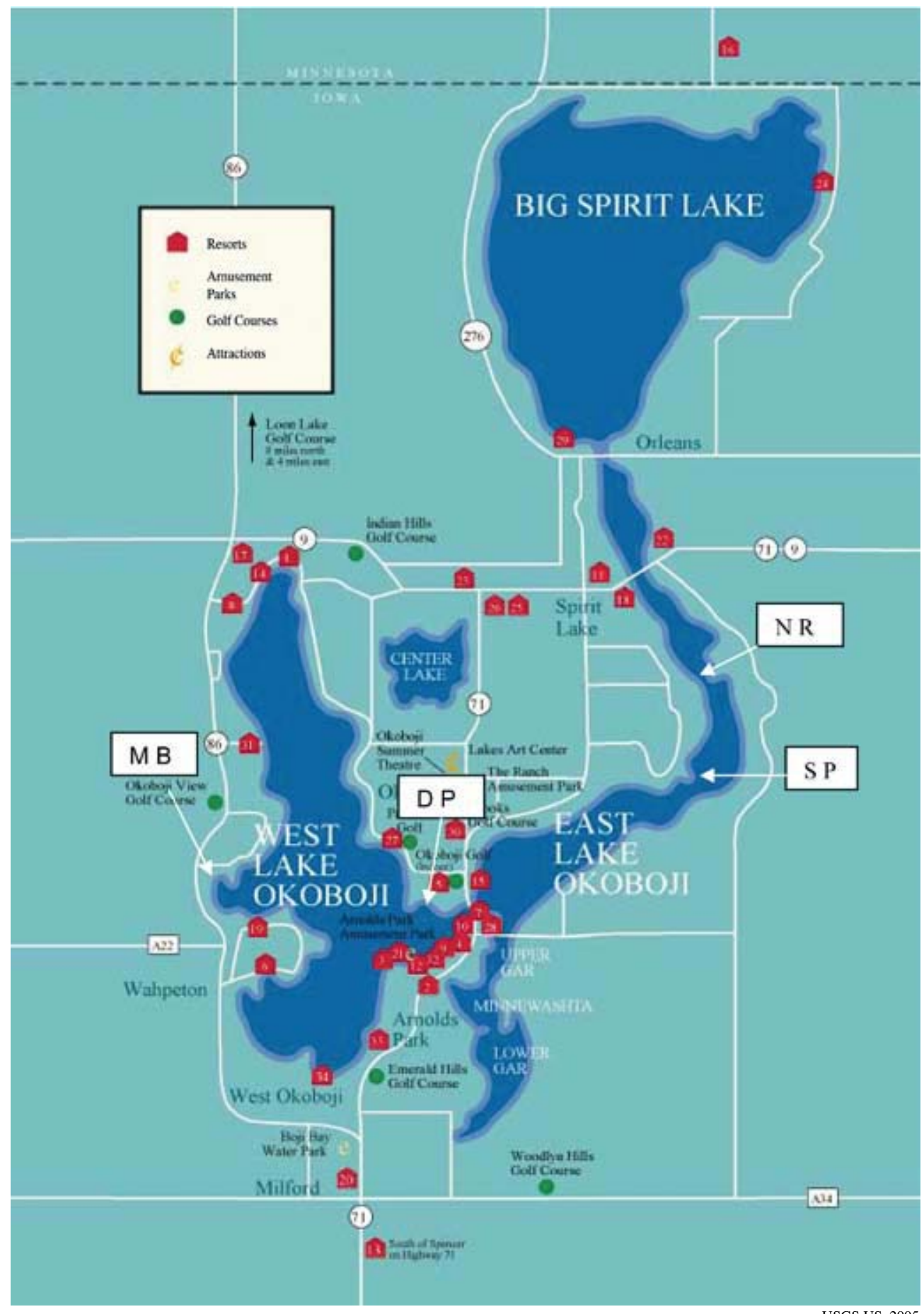

Figure 1. Lake's Area and Sampling Sites. 


\section{RESULTS AND DISCUSSION}

Table 1 provides some general information on each lake. These include, area, shoreline length, maximum depth, volume, mean depth, maximum length, and width.

Table 2 through Table 5, describe various physical and chemical measures obtained at each of the four stations from which data were collected. These include, depth, temperature, $\mathrm{pH}$, dissolved oxygen, conductivity, hardness, alkalinity, phosphate, nitrate, ammonia, and ammonium. Two of these measures, temperature and oxygen, are interpreted below because these are the ones that allow to determine thermic stratification and productivity (trophic status).

\subsection{RESULTS}

Table 1

Physical Characteristics of lakes. (Measurements from 1970 map)

\begin{tabular}{|l|r|r|}
\hline \multicolumn{1}{|c|}{ Lake } & $\begin{array}{c}\text { West Okoboji } \\
(\text { WOK })\end{array}$ & $\begin{array}{c}\text { East Okoboji } \\
(\text { EOK) }\end{array}$ \\
\hline Area (ha.) & 1,558 & 743 \\
\hline Length Shoreline (m) & 31,942 & 27,068 \\
\hline Maximum depth (m) & 41.5 & 6.7 \\
\hline Volume $\left(\mathrm{m}^{3}\right)$ & $178,578,600$ & $23,474,520$ \\
\hline Mean depth $(\mathrm{m})$ & 11.5 & 3.2 \\
\hline Maximum length $(\mathrm{km})$ & 8.8 & 5.2 \\
\hline Maximum width $(\mathrm{km})$ & 3.2 & 1.1 \\
\hline
\end{tabular}

\subsection{TEMPERATURE}

According to graphics 5 and 7 WOK presents some thermal stratification (thermocline) in both stations, but WOK:DP (Graphic $\mathrm{N}^{\circ} 7$ ) shows a clear thermocline (Wetzel, 1975; Horne \& Goldman 1994), presenting a high epilimnion almost until 19 meters deep, a slight metalimnion and a very confuse short hypolimnon behind 20 meter deep. WOK:MB (Graphic No 5) shows a clear epilimnion (0-1.5 m.); a metalimnion between 1.5 and $4.5 \mathrm{~m}$. (bottom) without a clear hypolymnion (Table 4 and 5).

In general, EOK is shallow (Table I, Graphic $\mathrm{N}^{\circ}$ 1, 3 and 5) but EOK:SP presents an epilimnion in between $0 \mathrm{~m}$. and $3.5 \mathrm{~m}$., a narrow metalimnion of $0.5 \mathrm{~m}$. and a very shallow hypolimnion. EOK:NR shows a surface metalimnion (temperature gradient) with not clear epilimnion.

\subsection{OXYGEN}

In WOK stations is possible to observe that the surface water are well oxygenated, may be due to the vertical mixing produced by the wind (Langmuir cells and spirals) Goldman \& Horne, 1994.

EOK: SP presents a well oxygenated surface water but NR only presents a thin layer $(0,5 \mathrm{~m}$.) and behind a depletion may be due to an organic charge that is corresponds with the behavior of $\mathrm{pH}$ and $\mathrm{NH}_{4}{ }^{+}$curves.

Table 2

Physical and Chemical data collected at station NR in EOK Conditions: hazy, sunny, windy

\begin{tabular}{|c|c|c|c|c|c|c|}
\hline Parameter & Unit & \multicolumn{5}{|c|}{ V a 1 u e } \\
\hline Secchi Disk & $\mathrm{m}$ & 0.63 & 0.725 & 0.73 & & \\
\hline Depth & $\mathrm{m}$ & 0.0 & 0.5 & 1.0 & 1.5 & 1.6 \\
\hline Temperature & ${ }^{\circ} \mathrm{C}$ & 22.3 & 22.2 & 22.1 & 22.1 & 22.9 \\
\hline $\mathrm{pH}$ & & 8.77 & 8.77 & 8.76 & 8.76 & 8.74 \\
\hline Dissolved Oxygen & $\mathrm{mg} / \mathrm{L}$ & 7.66 & 7.60 & 7.35 & 7.34 & 7.12 \\
\hline Conductivity & $\mathrm{mS} / \mathrm{cm}$ & 396 & 404 & 400 & 400 & 400 \\
\hline $\mathrm{NH}_{3}$ & $\mathrm{mg} / \mathrm{L}$ & 0.62 & 0.58 & 0.57 & 0.55 & 0.58 \\
\hline $\mathrm{NH}_{4}^{+}$ & $\mathrm{mg} / \mathrm{L}$ & 2.25 & 2.07 & 2.04 & 2.04 & 2.24 \\
\hline
\end{tabular}


Table 3

Physical and Chemical data collected at station SP in EOK Conditions: hazy, sunny, windy

\begin{tabular}{|l|l|r|r|r|r|r|r|r|r|r|}
\hline \multicolumn{1}{|c|}{ Parameter } & \multicolumn{1}{c|}{ Unit } & \multicolumn{9}{c|}{ V a l u e } \\
\hline Secchi Disk & $\mathrm{m}$ & 0.76 & 0.76 & 0.76 & & & & & & \\
\hline Depth & $\mathrm{m}$ & 0.5 & 1.0 & 1.05 & 2.0 & 2.5 & 3.0 & 3.5 & 4.0 & 4.2 \\
\hline Temperature & \multicolumn{1}{c}{${ }^{\circ} \mathrm{C}$} & 21.6 & 21.7 & 21.6 & 21.6 & 21.6 & 21.6 & 21.5 & 21.0 & 21.0 \\
\hline $\mathrm{pH}$ & & 8.79 & 8.80 & 8.80 & 8.79 & 8.79 & 8.80 & 8.80 & 8.63 & 8.69 \\
\hline Dissolved Oxygen & $\mathrm{mg} / \mathrm{L}$ & 9.48 & 9.46 & 9.45 & 9.24 & 9.24 & 9.28 & 9.34 & 6.25 & 6.55 \\
\hline Conductivity & $\mathrm{mS} / \mathrm{cm}$ & 404 & 404 & 404 & 402 & 404 & 404 & 404 & 400 & 402 \\
\hline $\mathrm{NH}_{3}$ & $\mathrm{mg} / \mathrm{L}$ & 0.93 & 0.85 & 0.83 & 0.77 & 0.80 & 0.72 & 0.69 & 0.46 & 0.50 \\
\hline $\mathrm{NH}_{4}{ }^{+}$ & $\mathrm{mg} / \mathrm{L}$ & 3.21 & 2.89 & 2.88 & 2.72 & 2.81 & 2.53 & 2.37 & 2.82 & 2.61 \\
\hline
\end{tabular}

Table 4

Physical and Chemical data collected at station MB in WOK Date: 091094. Conditions: hazy, sunny, windy

\begin{tabular}{|l|l|r|r|r|r|r|r|r|r|r|r|}
\hline \multicolumn{1}{|c|}{ Parameter } & \multicolumn{1}{|c|}{ Unit } & \multicolumn{9}{c|}{ V a l u e } \\
\hline Secchi Disk & $\mathrm{m}$ & 2.32 & 2.18 & 2.15 & 2.51 & & & & & & \\
\hline Depth & $\mathrm{m}$ & 0.1 & 0.5 & 1.0 & 1.5 & 2.0 & 2.5 & 3.0 & 3.5 & 4.0 & 4.5 \\
\hline Temperature & ${ }^{\circ} \mathrm{C}$ & 20.9 & 20.9 & 20.9 & 20.9 & 20.8 & 20.8 & 20.8 & 20.7 & 20.6 & 20.5 \\
\hline $\mathrm{pH}$ & & 8.55 & 8.54 & 8.54 & 8.55 & 8.55 & 8.56 & 8.56 & 8.56 & 8.52 & 8.42 \\
\hline Dissolved Oxygen & $\mathrm{mg} / \mathrm{L}$ & 8.76 & 8.78 & 8.77 & 8.78 & 8.80 & 8.80 & 8.79 & 8.85 & 8.26 & 0.82 \\
\hline Conductivity & $\mathrm{mS} / \mathrm{cm}$ & 392 & 396 & 396 & 396 & 396 & 396 & 396 & 394 & 394 & 396 \\
\hline $\mathrm{NH}_{3}$ & $\mathrm{mg} / \mathrm{L}$ & 0.93 & 0.72 & 0.61 & 0.54 & 0.48 & 0.47 & 0.44 & 0.40 & 0.30 & 0.25 \\
\hline $\mathrm{NH}_{4}{ }^{+}$ & $\mathrm{mg} / \mathrm{L}$ & 6.53 & 4.79 & 4.02 & 3.52 & 3.21 & 3.01 & 2.82 & 2.51 & 2.16 & 2.34 \\
\hline
\end{tabular}

Table 5

Physical and Chemical data collected at station DP in WOK Conditions: hazy, sunny, windy

\begin{tabular}{|c|c|c|c|c|c|c|c|c|c|c|c|c|c|c|c|c|c|c|c|}
\hline Parameter & Unit & \multicolumn{18}{|c|}{ Value } \\
\hline $\begin{array}{l}\text { Secchi } \\
\text { Disk }\end{array}$ & $\mathrm{m}$ & 2.3 & 2.62 & 2.88 & & & & & & & & & & & & & & & \\
\hline Depth & $\mathrm{m}$ & 0.1 & 1.0 & 2.0 & 3.0 & 4.0 & 6.0 & 8.0 & 10.0 & 12.0 & 13.0 & 14.0 & 15.0 & 16.0 & 17.0 & 18.0 & 19.0 & 20.0 & 21.0 \\
\hline Temp. & ${ }^{\circ} \mathrm{C}$ & 20.6 & 20.7 & 20.7 & 20.7 & 20.7 & 20.7 & 20.6 & 20.4 & 20.1 & 20.1 & 19.9 & 19.8 & 19.7 & 19.6 & 19.5 & 19.1 & 15.0 & 13.5 \\
\hline $\begin{array}{l}\text { Dissolv. } \\
\text { Oxygen }\end{array}$ & $\mathrm{mg} / \mathrm{L}$ & 8.39 & 8.35 & 8.31 & 8.36 & 8.34 & 8.29 & 8.29 & 7.40 & 6.69 & 6.46 & 5.91 & 5.39 & 5.19 & 4.75 & 4.45 & 3.22 & 0.74 & 0.80 \\
\hline Conduct & $\mathrm{mS} / \mathrm{cm}$ & 388 & 394 & 396 & 394 & 394 & 394 & 394 & 394 & 392 & 394 & 392 & 392 & 392 & 394 & 392 & 390 & 378 & 364 \\
\hline $\mathrm{NH}_{3}$ & $\mathrm{mg} / \mathrm{L}$ & 0.8 & 0.6 & 0.5 & 0.46 & 0.42 & 0.34 & 0.33 & 0.25 & 0.21 & 0.19 & 0.17 & 0.15 & 0.15 & 0.14 & 0.12 & 0.09 & 0.05 & 0.04 \\
\hline
\end{tabular}




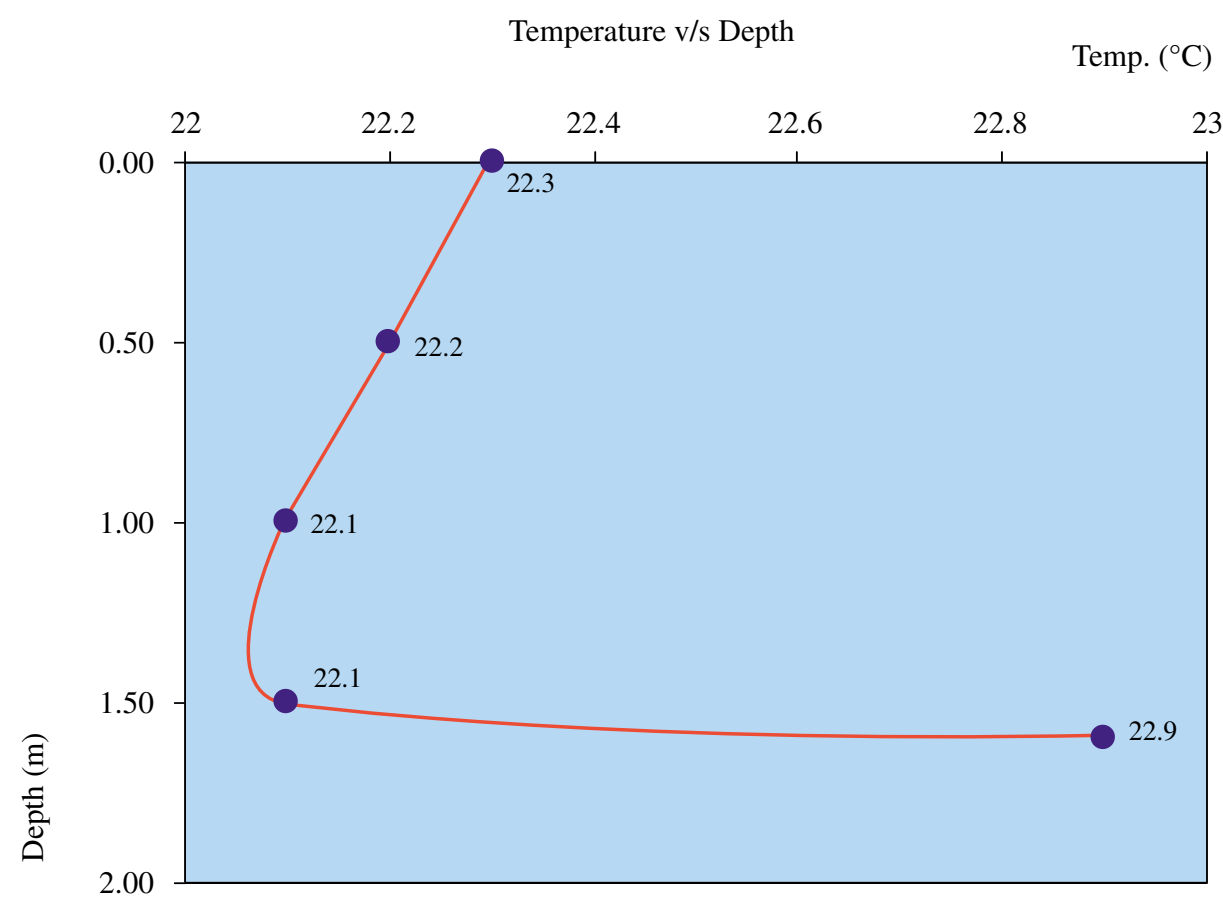

Graphic $\mathbf{N}^{\mathbf{1}}$ 1. Station NR in EOK.

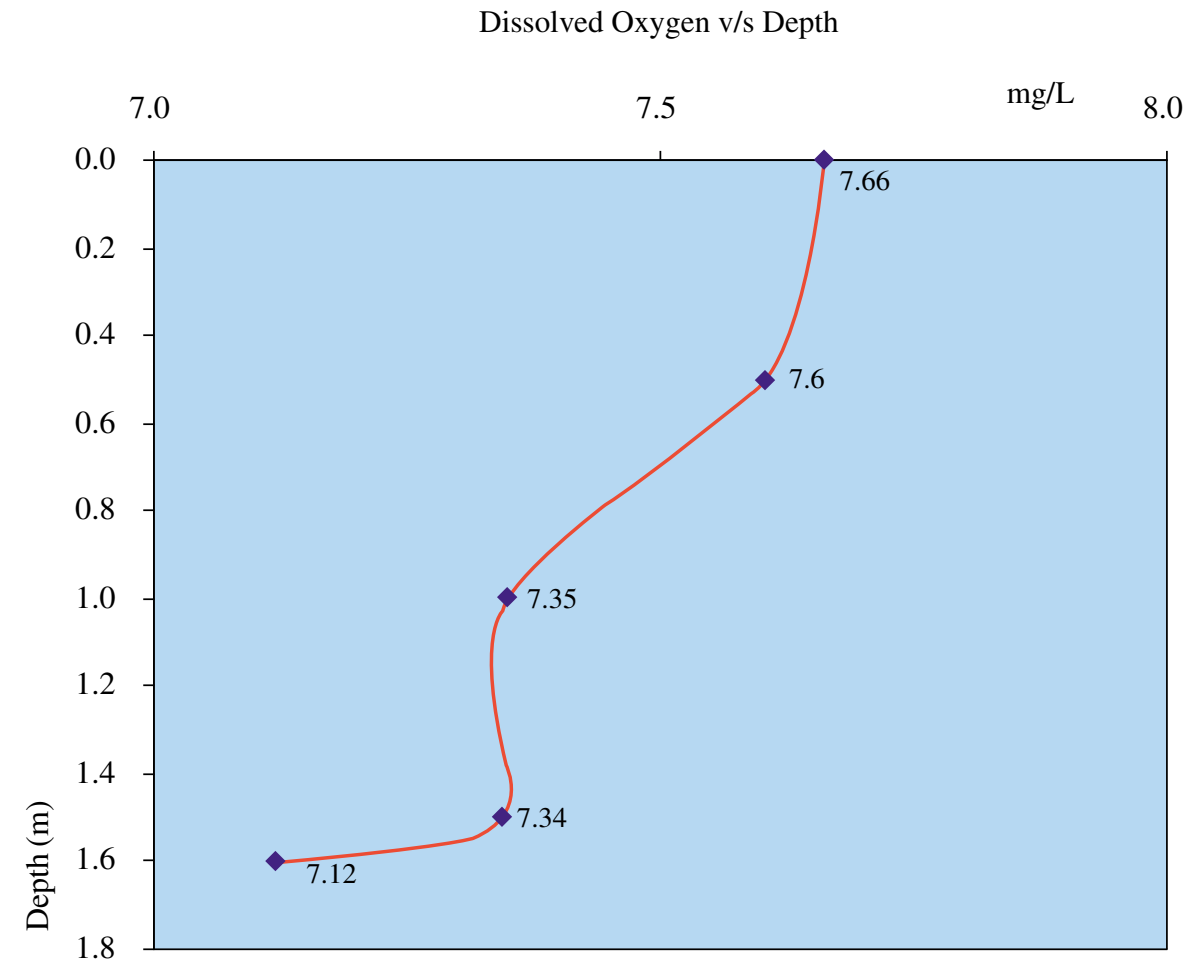

Graphic $\mathbf{N}^{\circ}$ 2. Station NR in EOK. 


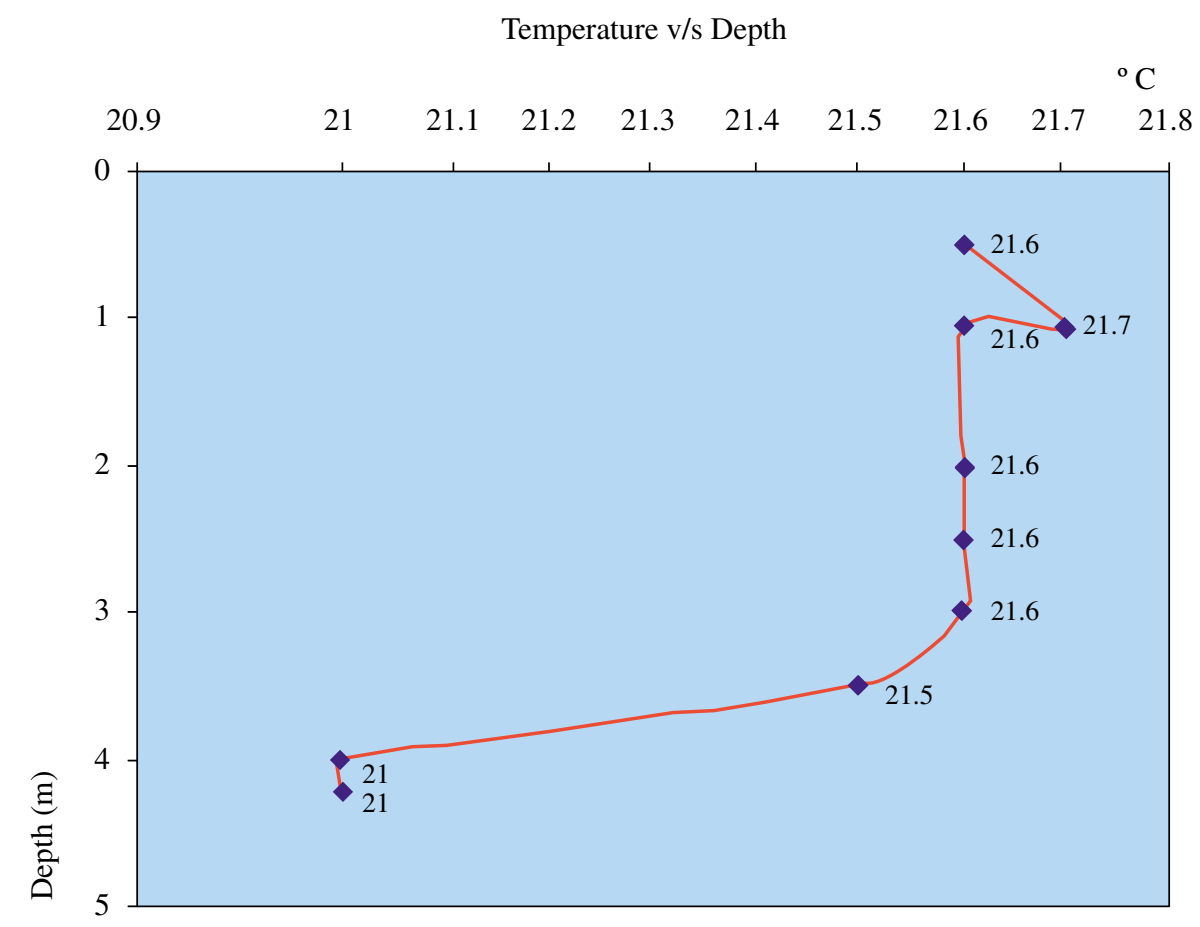

Graphic $\mathbf{N}^{\mathbf{0}}$ 3. Station SP in EOK.

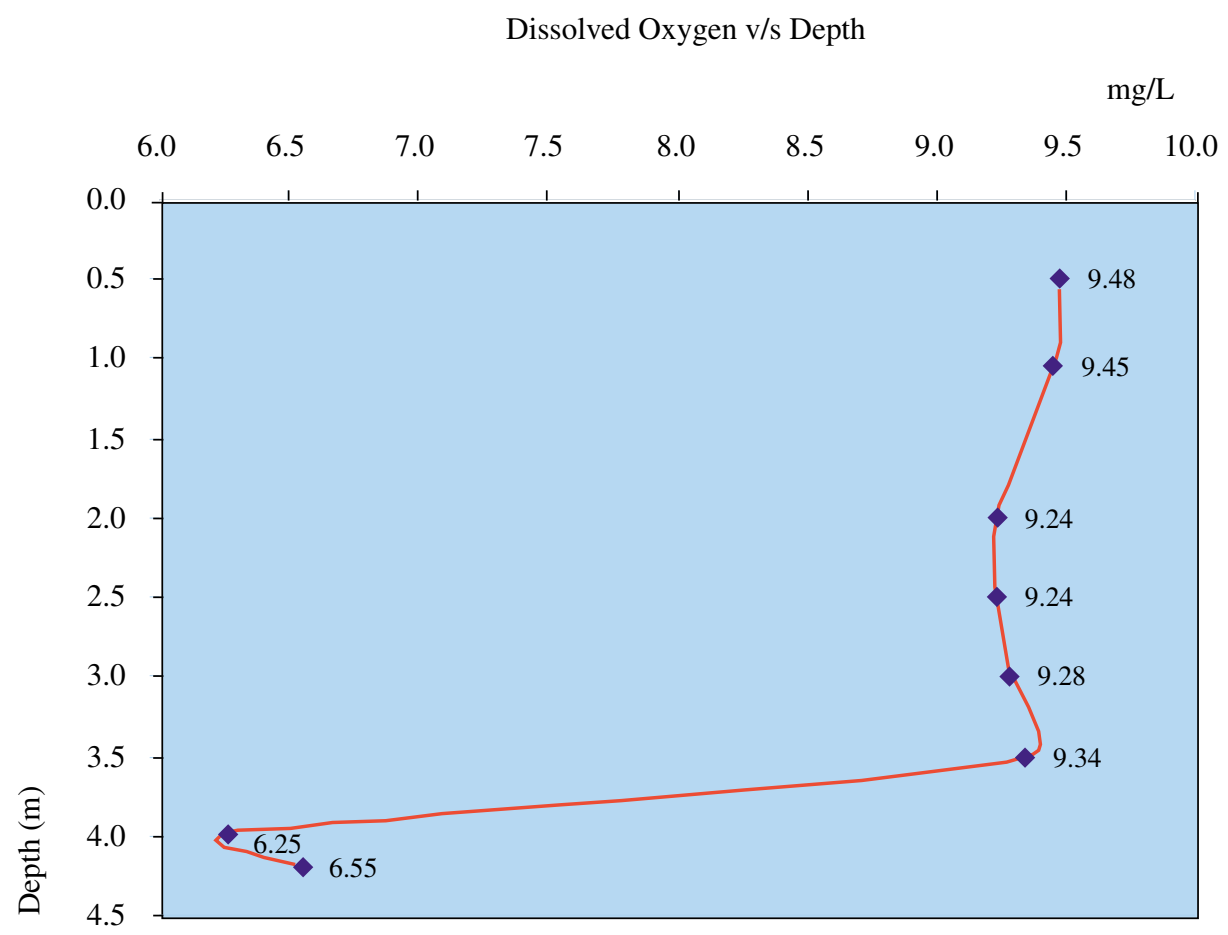

Graphic $\mathbf{N}^{\circ}$ 4. Station SP in EOK. 


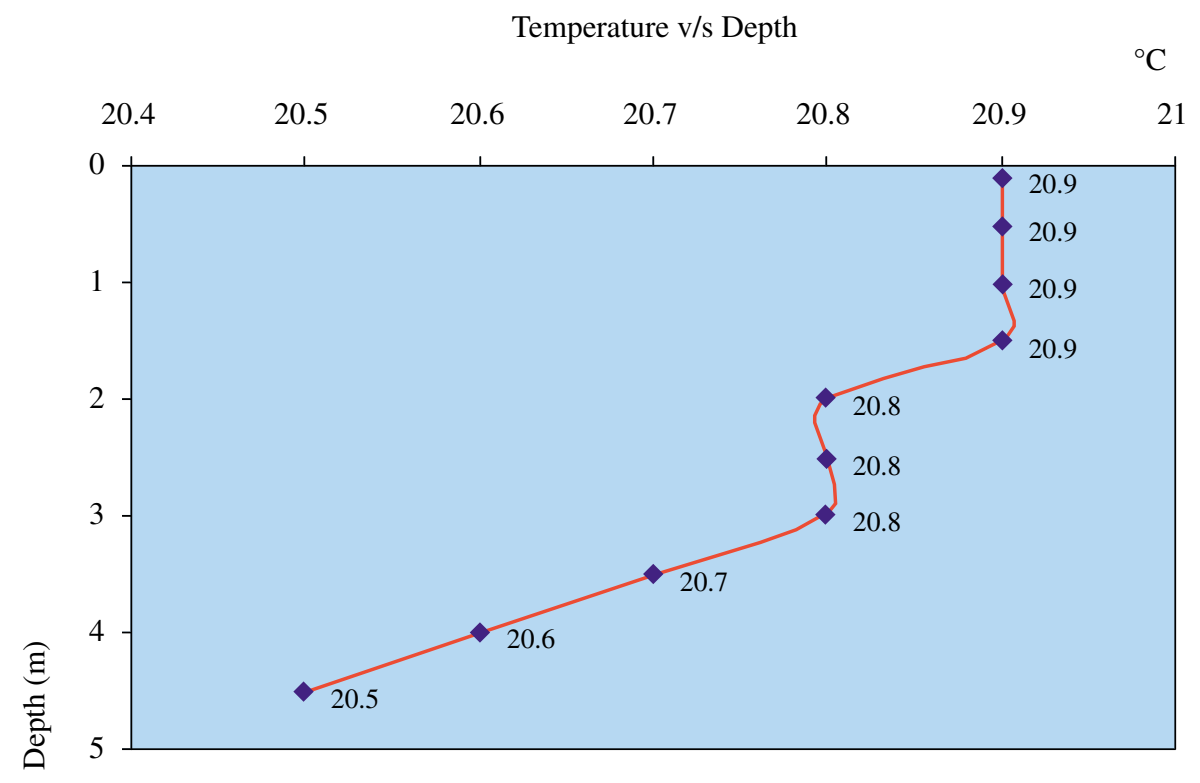

Graphic $\mathbf{N}^{\circ}$ 5. Station MB in WOK.

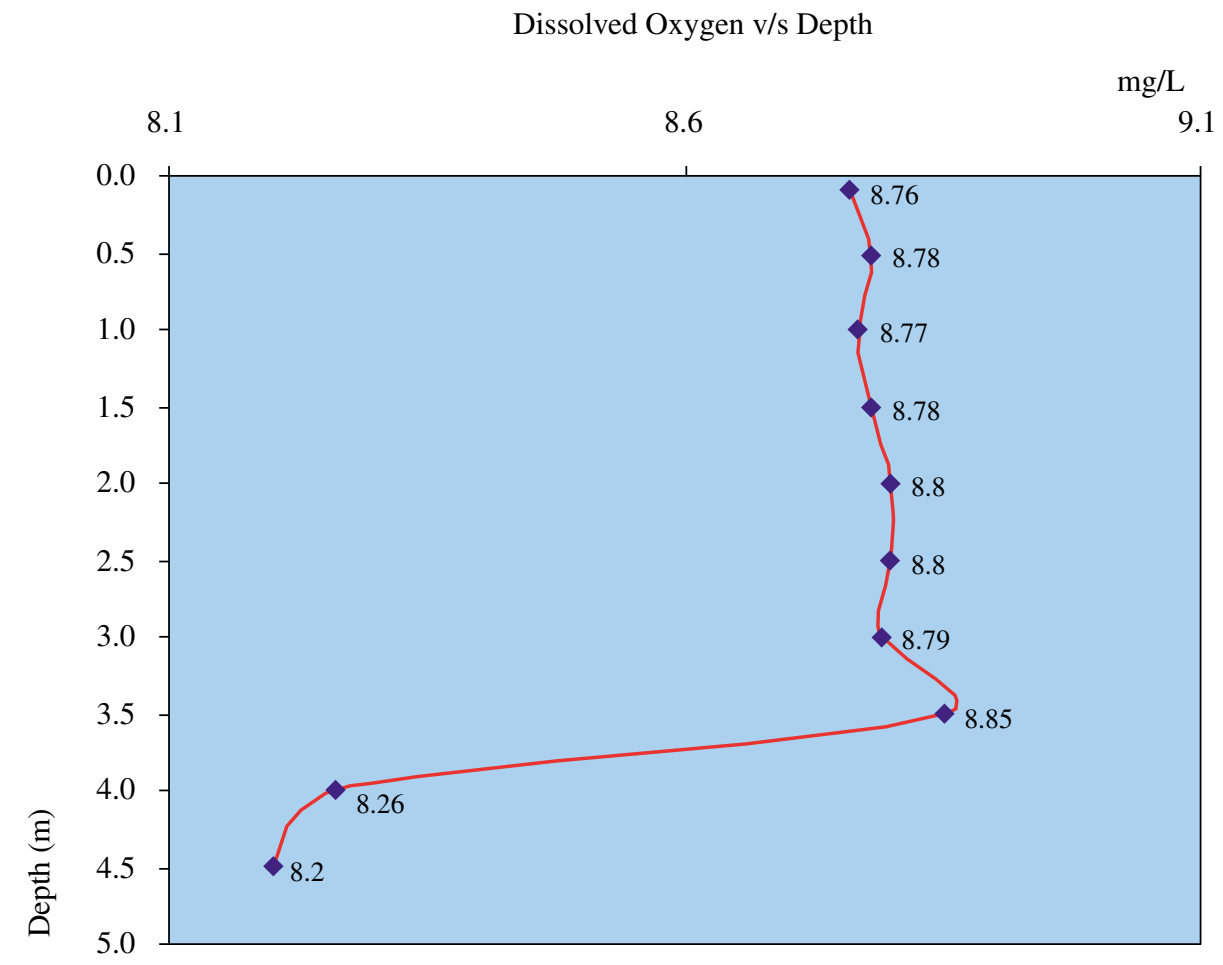

Graphic $\mathbf{N}^{\mathbf{0}}$ 6. Station MB in WOK. 


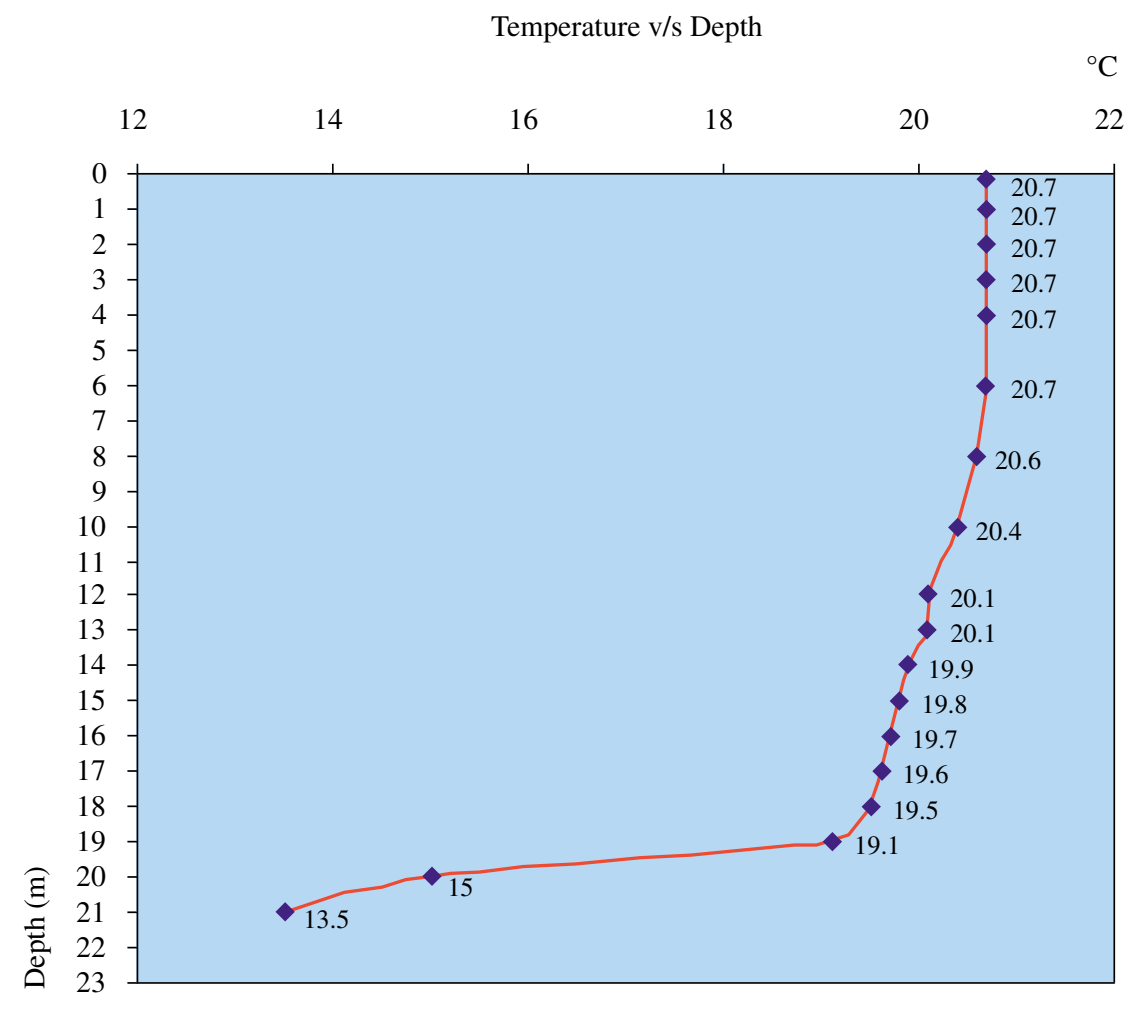

Graphic $\mathbf{N}^{\mathbf{0}}$ 7. Station DP in WOK.

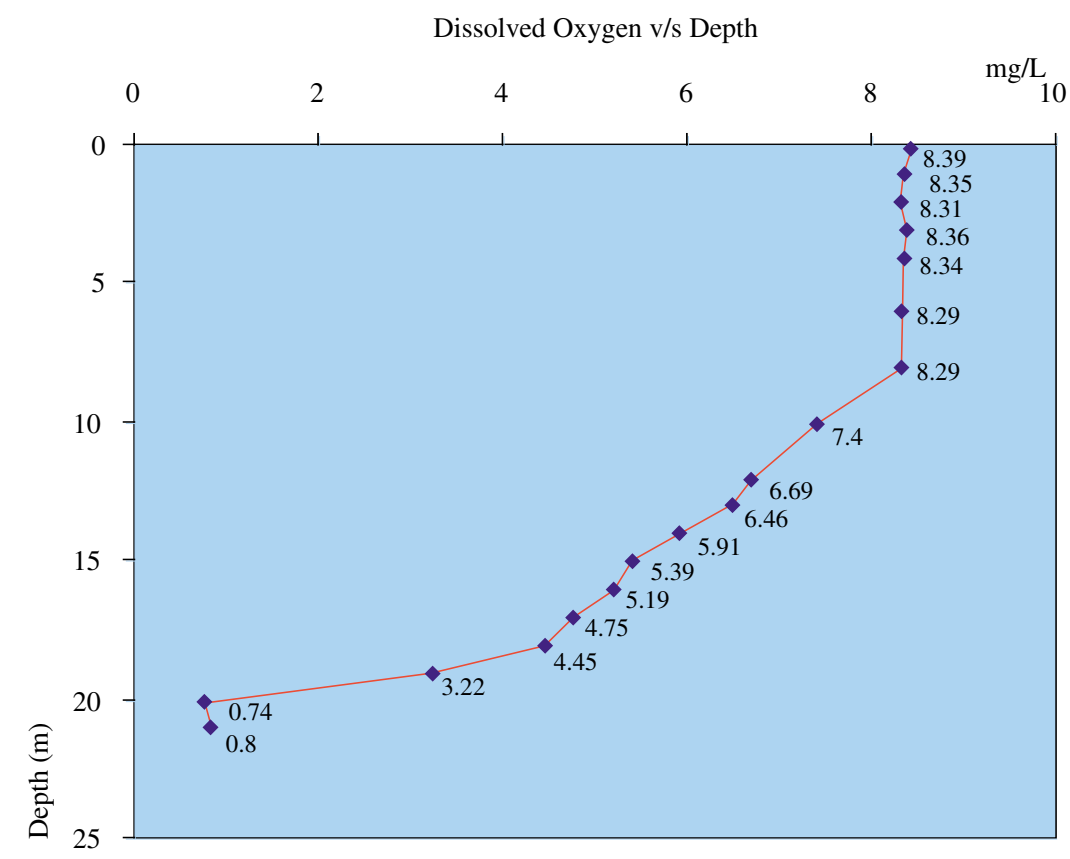

Graphic $\mathbf{N}^{\mathbf{0}}$ 8. Station DP in WOK. 


\subsection{COMPARISON BETWEEN LAKES}

A one-way ANOVA was performed to examine differences in Chlorophyll $\mathrm{A} \mathrm{mg} / \mathrm{m}^{3}(\mathrm{Ch})$ and in Ash-free dry weight $\mathrm{mg} / \mathrm{m}^{3}$ (Wt) between East Okoboji and West Okoboji separately for samples taken at each of the following depths: surface and 2 meters deep. No statistically significant differences in chlorophyll were observed between samples taken from the surface waters $(\mathrm{F}(1.10)=4.89, \mathrm{p}<0.051)$. At this depth, however, there were statistically significant differences in ash-free dry weight $(\mathrm{F}(1,10)=47.22, \mathrm{p},<0.0001)$. At the 2-meter depth, there were statistically significant differences between East and West Okoboji in terms of chlorophyll $(\mathrm{F}(1.10)=12.36$, p. $<0.005)$ and ash-free weight $(F(1.10)=100.41$, p. $<0.0001)$.

\subsection{COMPARISON AMONG STATIONS}

A second one-way ANOVA was performed to examine differences in Chlorophyll A mg/m3 (Ch) and in Ash-free dry weight $\mathrm{mg} / \mathrm{m} 3$ (Wt) as a function of the four stations, two in East Okoboji and two in West Okoboji. The analysis was performed separately at each of the following depths: surface and 2 meters deep. Results indicate that among the samples taken from the surface water, there were statistically significant differences in chlorophyll $(\mathrm{F}(3.8)=4.46, \mathrm{p}<0.040)$ and ash-free weight $(\mathrm{F}(3.8)=40.77, \mathrm{p}<0.0001)$. A Duncan Multiple Range test was performed to examine the nature of these differences. It showed that only Station SP in East Okoboji differed from the other three with respect to chlorophyll. With respect to ash-free weight, Station SP $(M=16133)$ in East Okoboji differed from Station NR (11200) which is also in East Okoboji, as well as the two stations in West Okoboji (DP M = 4467 and MB M = 3933). Station NR differed significantly from Stations DP and MB. Stations DP and MB, both in West Okoboji, did not differ from each other.

At the 2-meter depth, there were statistically significant differences in chlorophyll $(\mathrm{F}(3.8)=26.49$, $\mathrm{p}<0.0002)$ and ash-free weight $(\mathrm{F}(3.8)=64.04$, $\mathrm{p}<0.0001)$. A Duncan Multiple Range test was performed to examine the nature of these differences. It showed that Station SP $(M=42.29)$ in East Okoboji differed from the other three with respect to chlorophyll. Station NR $(M=13.41)$ also in East Okoboji differed from DP $(\mathrm{M}=0.80)$ but not from MB $(\mathrm{M}=3.73)$. With respect to ash-free weight, Station SP $(M=18.889)$ in East Okoboji differed from Station NR (14.978) which is also in East Okoboji, as well as the two stations in West Okoboji (DP M = 1767 and MB M = 4267). Differences were also observed between NR and MB as well as DP. Stations MB and DP did not differ from each other.

\subsection{BETWEEN LAKES COMPARISONS ON ZOOPLANKTS}

The two lakes were also compared on three measures of zooplankts. The results showed that the lakes did not differ on cladocerans $(\mathrm{F}(1.10)=$ $2.50 \mathrm{p}<0.14)$, calanoids $(\mathrm{F}(1.10)=0.05 \mathrm{p}<0.82)$, cyclopoids $(\mathrm{F}(1.10)=0.22 \mathrm{p}<0.22)$, and total amount of zooplankts. $(\mathrm{F}(1.10)=0.76 \mathrm{p}<0.40)$.

\subsection{AMONG STATIONS COMPARISONS ON ZOOPLANKTS}

The four stations were also compared on these measures of zooplankts, these results show that the four stations did not differ on cladocerans $(\mathrm{F}(3.8)=$ $1.68 \mathrm{p}<0.24)$, calanoids $(\mathrm{F}(3.8)=1.63 \mathrm{p}<0.25)$, and total $(\mathrm{F}(3.8)=1.57 \mathrm{p}<0.27)$. The zooplankt is similar to those of andean lakes (Sanzana, 1985). Statistically significant differences were observed in cyclopoids $(\mathrm{F}(3.8)=4.30 \mathrm{p}<0.043)$. Duncan's test showed that Station DP $(M=1.59)$ and Station SP $(\mathrm{M}=0.73)$ did not differ from each other. Station SP differed from NR $(M=0.713)$ and $M B(M=0.220)$. No other pairwise differences were significant.

\section{SUMMARY OF THE RESULTS AND DISCUSSION}

During the sailing to collect the data, it was observed that these wind-driven cells could be mixing in the shallower places of both lakes. This could explain the behavior of some oxiclines in some stations, specially in the shallow ones (Graphics $2,4,6$ y 8$)$.

No statistically significant differences in chlorophyll were observed between samples taken from the surface waters but differences were observed at 2-meter depth. Statistically significant differences in ash-free dry weight were found at both depths. 
With surface waters it was found that station SP in East Okoboji differed from the other three with respect to chlorophyll. With respect to ash-free weight differences were observed between the two stations in East Okoboji as well as between the to EOK stations and the WOK. Both WOK stations were similar on this variable. At the 2-meter depth, Station SP in East Okoboji differed from the other three with respect to chlorophyll. Station NR also in East Okoboji differed only from one station in WOK:DP. With respect to ash-free weight, Station SP East Okoboji differed from Station NR (14978) which is also in East Okoboji, as well as the two stations in West Okoboji. The two stations in WOK did not differ from each other. With respect to zooplankts, no differences were observed between lakes. There were differences among stations with

\section{BIBLIOGRAPHY}

HORNE, A. J. \& C. R. GOLDMAN. 1994. Limnology. McGraw-Hill, Inc.

MLADINIC, P., E. QUINTANA Y N. HREPIC. 1984. Parámetros Físicos y Químicos de las Aguas de los Lagos Chungará y Cotacotani. I Región (Chile).

THOMANN, R., W. VILLWOCK, L. KIES, F. THIEDIG. 1985. Investigaciones Geológicas y Ecológicas en el Lago Chungará/ Norte de Chile: Objetivos y Primeros Resultados. Idesia (Chile), Vol. 9. respect to cyclopoids. Station WOK:DP and Station EOK:SP did not differ from each other. Station EOK:SP differed from EOK:NR and WOK:MB.

These findings suggest that the two stations in WOK yield fairly consistent data. In EOK, however, several differences were found between the two stations. This could be due to differences in depth which in turn affect temperature and nutrients (Wetzel, 1975; Thomann et al., 1985).

From the evolution of the curves, it was possible to observe that EOK is a shallow lake that presents oxygen depletion, probably due to a high organic charge from natural or anthropic origin and is almost totally mixed because the wind. The parameter analyzed indicate an eutrophic lake. WOK because the behavior of the analyzed parameter could be a mesotrophic lake.
WETZEL, R. G. 1975. Limnology. W. B. Saunders Company.

SANZANA, J. 1985. Contribución al Conocimiento de la Biocenosis del Lago Chungará (Parinacota-Chile).

SANZANA, J. 1984. Estudio Limnológico en el Lago Chungará. Informe Final de Investigación. Universidad de Tarapacá, Departamento de Investigación y Desarrollo Científico. Arica, 21 p. 